\title{
Spatio-temporal variations in reproductive patterns and population structure of Pasiphaea multidentata (Decapoda: Caridea) in the Blanes canyon and adjacent margin, North-western Mediterranean Sea
}

Eva Ramirez-Llodra ${ }^{1,2}$, Joan B. Company ${ }^{1}$, Mercedes Camps ${ }^{1}$, Guiomar Rotllant ${ }^{3}$

${ }^{1}$ Institut Ciències del Mar, CSIC, Psg. Marítim de la Barceloneta 37-49, 08003 Barcelona, Spain

${ }^{2}$ National Oceanography Centre, European Way, SO14 3ZH Southampton, UK

${ }^{3}$ Institut de Recerca Tecnologica Agricola, Carretera del Poblenou Km 5.5, 43540 Sant Carles de la Ràpita, Spain.

Corresponding author: ezr@icm.csic.es, Tel: +34 932309544

\section{Abstract}

\section{Introduction}

The bathyal faunal communities of the NW Mediterranean slopes have been studied consistently in the last two decades, with a special focus on population structure, trophic dynamics and benthopelagic coupling of commercial deep-sea decapod crustaceans and fishes (reviewed in Sardà et al. 2004) and associated species (Cartes and Sardà, 1993; Company and Sardà, 1997, 2000; Cartes et al., 2001; Company et al., 2001, 2003, 2004). One of the major topographic features in the North-western Mediterranean slope is the presence of submarine canyons. Canyons play a major role in funnelling energy and organic matter from the shelf to bathyal and abyssal depths (Puig et al., 2000), but the implications of this enhanced organic supply in the deep-sea benthic communities is still mostly unknown. Trophic supply can follow two major pathways - vertical deposition in the water column (Billett et al., 1983; Baldwin et al., 1998; Lampitt et al., 2001) or down-slope advection on the margins (Puig et al., 2001; Bethoux et al., 2002; Canals et al., 2006) - and can be a limiting factor in the deep- 
sea, being especially important in the oligotrophic Mediterranean Sea (Sardà et al., 2004). Differences in the quantity, quality and timing of organic matter input to the deep seafloor have been used to explain patterns of biomass and abundance in benthic communities (Levin et al., 1994; Gooday \& Turley, 1990; Billett et al., 2001; Galéron et al., 2001; Puig et al., 2001; Gage, 2003) as well as other biological process and in particular the existence of seasonal reproduction (Tyler et al., 1994; Company et al., 2004 (MEPS). Reproduction is a highly energetic process tightly linked to food availability and quality.

Pasiphaea multidentata is a deep-water caridean shrimp living between 200 and 2000 m depth in Mediterranean and Atlantic waters (Gonzalez-Gurriaran and Olaso, 1987). This species undergoes diel vertical migrations. $P$. multidentata predates on gammarids, amphipods and isopods on the benthic boundary layer and is the prey of a variety of decapod crustaceans and fishes (Cartes, 1993; Cartes et al., 1993; Bozzano et al., 1997; Baeur, 2004). The daily vertical migrations of $P$. mulidentata play a major role in the transfer of energy between the pelagic and benthic layers of the North-western Mediterranean continental margin. The biological aspects of $P$. multidentata and congeneric species $P$. sivado from the NW Mediterranean Sea have been studied and related to depth of distribution (Company et al., 2001). The results showed that the shallower species, $P$. sivado, undergoes continuous reproduction and has a higher reproductive output than $P$. multidentata. In addition to its important ecological role in the ecosystem, $P$. multidentata is also an important by-catch of Mediterranean fisheries targeting the deep-water red shrimp Aristeus antennatus. While A. antennatus is one of the main commercial species in the Mediterranean, $P$. multidentata is only found in Spanish markets and occasionally in Italy, Morocco and Greece, being discarded in the other countries. It has been shown that the populations of $A$. antennatus have important spatial and temporal sex and size segregations that have been related to processes linked with energy transfer down canyon systems, food resources and intraspecific competition (Sarda et al., 1997). In this study we have described the seasonal 
gametogenetic patterns of $P$. multidentata and have analysed the spatio-temporal variations in its population structure and reproduction to determine if the canyon and slope habitats have an effect in the populations of $P$. multidentata similar to that observed for A. antennatus.

\section{Material and Methods}

The samples of $P$. multidentata were collected by commercial fishing bottom trawlers in 3 sites on and around the Blanes canyon: 1) the canyon head (canyon) between 364 and $585 \mathrm{~m}$ depth; 2) the canyon wall (wall) between 384 and 585 m depth; and 3) the adjacent continental margin (margin) between 512 and 700 m depth (Figure 1). Each site was sampled using a commercial bottom otter trawl with a 3 m mouth opening fitted with a $6 \mathrm{~mm}$ mesh cod-end liner. The sampling was conducted regularly on a monthly basis, covering an annual cycle between April 2003 and April 2004 (Table 1). This study is part of the project RECS II (REF, in prep?), which conducted an integral study of the Blanes canyon in relation to the exploitation of the red shrimp Aristeus antennatus. The samples were sorted, measured, weighted and sexed on board. Ten females of $P$. multidentata were preserved in buffered seawater formaldehyde and stored in 70\% ethanol for histological analyses of gametogenesis.

The cephalothorax (CL) of all specimens was measured from the eye socket to the middle of the carapace margin. The CL size was used to plot the population structure for each sample. The specimens were sexed and the sex ratio plotted for each sample. Gender was determined under a binocular microscope based on the presence or absence appendix masculina on the second pair of pleopods of males. Individuals with carapace lengths smaller than $21 \mathrm{~mm}$ have no discernible external secondary sex structure and were classified as indeterminate, individuals with $\mathrm{CL}<30 \mathrm{~mm}$ are juveniles with no mature gonads and individuals with CL> $30 \mathrm{~mm}$ CL are adults (Company et al., 2001). Sex ratio was plotted for each sample and differences tested with chi-square. Sexual maturity of females was described in relation to the gonad external morphology and using the ovary development stages defined 
in Company et al., 2001: Stage I, immature females; Stage II, rest, with small and white ovary; Stage III, initiation of maturation, with ovary enlarging and more opaque; Stage IV, maturation, with ovary extending in the cephalothorax and the colour changing to red; Stage V, mature ovary occupying most of the cephalothorax, sometimes with dorsal extensions in the abdomen, a slightly red colour and visible oocytes.

The gametogenetic studies were conducted in 5 to 10 females from each site sampled in spring, summer, autumn and winter. The ovaries were dissected out, dehydrated in graded alcohols, cleared with Clear $^{\circledR}$ liquid and embedded in paraffin wax. Paraffin sections were cut at $7 \mu \mathrm{m}$ and stained with Haematoxylin and Eosin. All oocytes sectioned through the nucleus ( $\mathrm{n}=50$ to 120 per individual) were measured (feret diameter) using SigmaScan Pro5. The measurements were grouped in $50 \mu \mathrm{m}$ size classes and the percentage frequency of oocytes-sizes calculated for each size-class in each individual. The pooled oocyte-size data (mean \pm standard deviation) was plotted for each sample (site and month).

\section{Results}

\section{Population structure}

The population structure of $P$. multidentata was compared amongst populations in the three sampling sites throughout the year (Figure 2). The samples collected in spring in the margin showed the presence of 3 cohorts: a first peak of small indeterminate individuals ( $\mathrm{CL}<20 \mathrm{~mm}$ ) marking the recruitment season, a second peak of juveniles $(C L=20-30 \mathrm{~mm})$ and a third smaller group of large mature males and females (CL> $30 \mathrm{~mm}$ ). The wall and canyon site follow a similar pattern with the exception of indeterminate individuals, which could be a consequence of the small sample size. In summer, the populations of the 3 sites have a similar structure, with two main cohorts: a first one composed by juveniles $(C L=20-30 \mathrm{~mm})$ and a second one of mature males and females (CL> $30 \mathrm{~mm})$. In autumn, the populations at the 3 sites are composed by a group of juveniles coming from the previous 
recruitment season and a group of large adults with maturing gonads. In late winter, the populations are mainly composed by juveniles and young adults.

\section{Sex ratio}

The sex ratio showed significant differences from the 1:1 expected ratio in the populations from all sites and seasons (Chi Square, $\chi^{2}, \mathrm{df}=1, \alpha<0.001$ ) except for the samples from spring/canyon and summer/margin $(\alpha<0.005)$ and spring/wall $(\alpha<0.01)$. Females dominated the populations at all times and there were no significant differences in the proportion female/male between sites (Figure 3).

\section{Ovary maturation cycle}

Figure 4 shows the percentage of females with ovaries at different development stages in the 3 sites, grouped by season. The pattern is similar in the three sites. Over $40 \%$ of the female population had ovaries in the rest stage (II) throughout the year at all sites. Gonads in the resting and early developmental stages (II and III) are found in spring. The maturation of ovaries (stage III) is initiated in summer. Mature gonads (stages IV and V) are found in summer and autumn, and in winter most females are again at the resting ovary stage. The populations from the margin and canyon head have the highest proportion of mature females in summer (Figure 4A,C), while the population from the canyon wall shows a slight delay in the maturation of females, with a higher proportion of females in stages IV and $\mathrm{V}$ in autumn (Figure 4B).

\section{Gametogenesis}

The ovaries of $P$. multidentata are paired organs overlaying the digestive gland. The immature and resting ovary is small and white. As the ovary matures, the two lobes extend dorsally towards the abdomen and become more opaque and red in colour. In fully mature females, the ovaries occupy most 
of the dorsal cephalothorax and can extend as two dorsal filaments down to the $4^{\text {th }}$ segment of the abdomen. These ovaries a red in colour and the oocytes are densely packed and visible to the naked eye. The histological sections showed previtellogenic oocytes characterised by their large nucleus/cytoplasm ratio and basophilic cytoplasm that stains purple with haematoxylin (Figure 5A,B). During development, the growing previtellogenic oocytes migrate from the periphery of the gonad towards the centre (Figure 5A). The previtellogenic oocytes grow to approximately 180-200 $\mu \mathrm{m}$ in diameter before undergoing vitellogenesis. The onset of vitellogenesis is characterised by the presence of lipidic granules in the cytoplasm and a change to acidophila, resulting in the oocytes staining pink with eosin (Figure 5C,D). The vitellogenic oocytes have a small nucleus/cytoplasm ratio and are surrounded by a mono-layer of follicular cells (Figure 5D). The maximum oocyte size measured at each site was $1418 \mu \mathrm{m}$ for a female sampled on the canyon, $1281 \mu \mathrm{m}$ for a female sampled on the wall site and $1263 \mu \mathrm{m}$ for a female sampled on the margin.

\section{Oocyte-size distributions}

The overall distribution of oocyte sizes throughout the year was similar for the females sampled at the three sites (Figure 6A-D). In winter, the ovaries were in an early stage of development, with most oocytes between 100-300 $\mu \mathrm{m}$ diameter, corresponding to previtellogenic and early vitellogenic stages. The largest oocytes ranged between 430 and $640 \mu \mathrm{m}$, except in one individual from the canyon, which had a few vitellogenic oocytes reaching $1400 \mu \mathrm{m}$ (Figure 6A). These could be non-spawned oocytes in the process of re-absorption. The ovaries of females sampled in spring had a slightly bimodal oocytesize distribution, with a first peak in the $200 \mu \mathrm{m}$ size-class corresponding to previtellogenic oocytes and a second peak of early vitellogenic oocytes at around $400 \mu \mathrm{m}$ (Figure 6B). The largest oocytes ranged between 540 and $590 \mu \mathrm{m}$. In summer, the diagram of oocytes-sizes followed a bimodal distribution, again with a peak of previtellogenic oocytes around $200 \mu \mathrm{m}$ and a second extended mode of larger vitellogenic oocytes between 600 and $1000 \mu \mathrm{m}$ in diameter (Figure 6C). The largest oocytes ranged 
between 1040 and $1280 \mu \mathrm{m}$. Finally, the females sampled in autumn presented a marked bimodal distribution of oocytes sizes, with a first peak of previtellogenic oocytes and a second peak of large vitellogenic oocytes ranging between 600 and $1400 \mu \mathrm{m}$ (Figure 6D). The largest oocyte sizes ranged between 1260 and $1420 \mu \mathrm{m}$. The overall largest oocyte sizes were found in females from the canyon population in all seasons excluding spring. However, the analysis of variance for maximum oocyte size with season and site was only significant for season $(\mathrm{F}=22.031, \mathrm{df}=3, P<0.001)$, with maximum size increasing from winter (February sample) to autumn (September sample) and no significant differences in mean largest oocyte size amongst populations $(\mathrm{F}=1,357, \mathrm{df}=2, P=0.264)$. The mean size of vitellogenic oocytes - after excluding the individual with oocytes $>650 \mu \mathrm{m}$ sampled in winter in the canyon - increased between February and September, with no significant differences between sites (Figure 7).

\section{Discussion}

The data presented in this study indicate that there were no major differences in the population structure and reproductive biology of Pasiphaea multidentata at the 3 study sites in the Blanes canyon and adjacent margin in the NW Mediterranean. The population structure followed similar trends in the 3 sites, with non-reproductive individuals $(\mathrm{CL}<30 \mathrm{~mm})$ present in the populations collected in spring and summer and large mature individuals (CL> $30 \mathrm{~mm}$ ) dominating in autumn and winter. This coincides with the population structure described by Company et al. (2001) for a population of $P$. multidentata from the Barcelona margin. The populations of $P$. multidentata where dominated by females at the three sites and all seasons. The depth of maximum abundance for $P$. multidentata is 550 m, with a depth distribution range between 128 and $2261 \mathrm{~m}$. It has been shown that large individuals of P. multidentata (CL $>30 \mathrm{~mm}$ ) stay close to the seafloor during day and night, undergoing only short diel migrations (Company et al., 2001; Aguzzi et al., 2007), while females are commonly found deeper in the population's distribution range (Cartes and Sarda, 1992; Cartes et al., 1993). This could explain 
the higher proportion of females sampled at all sites and also observed by Company et al. (2001) in the Barcelona population. The dominance of females has also been described for the deep-water red shrimp Aristeus antennatus, which is the main crustacean target for Mediterranean fisheries to which $P$. multidentata is associated. Studies on spatio-temporal distributions of $A$. antennatus have shown that this species in the NW Mediterranean has important sex and size distribution segregations, with a higher proportion of males and juveniles between 1000-2200 m depth (Sarda and Cartes, 1993) and a higher proportion of females above $1000 \mathrm{~m}$ depth. A. antennatus has a seasonal reproductive pattern, with maturation of gonads in spring and summer (Demestre and Fortuño, 1992) and it has been shown that the proportion of reproductive females increases on the middle slope $(\sim 650 \mathrm{~m})$ in spring and summer, while between late summer and early winter the population spreads over entering shallower waters in the canyons (Sarda et al., 1994; Sarda et al., 1997). Although P. multidentata has also a seasonal reproductive cycle, with mature individuals in winter (Company et al., 2001), the present results do not show a spatio-temporal variation in population structure similar to that observed for $A$. antennatus. While $A$. antennaus is a dominant benthic species on the upper and middle slope, $P$. multidentata is bathypelagic with extensive diel vertical migrations, mainly on the small and medium size individuals, while the large specimens stay close to the bottom even at night (Cartes et al., 1993). Because A. antennatus has a strong benthic character, the spatio-temporal variations in its population distribution can be related to seafloor characteristics, such as seasonal variations in food availability and intra-specific competition for limited resources (Sarda et al., 1997). In the case of P. multidentata, its benthopelagic behaviour may explain the lack of differences in population structure between sites, as the species is less linked to seafloor processes.

The gross morphology and microscopic examination of ovaries confirmed the seasonal reproductive cycle of $P$. multidentata from the NW Mediterranean, previously reported by Company et al. (2001) from gross morphology analyses in a population on the slope off Barcelona. The patterns are similar in 
the Blanes and Barcelona populations, with a clear active reproductive period during the late summer and autumn months. Ovary maturation starts in late spring and the highest proportion of females with well developed ovaries are found in summer. The patterns were also similar in the 3 study sites, but the population sampled on the canyon wall seems to have a slight delay in the maturation of females as the highest proportion of females with well developed ovaries (stage V) was found in the autumn samples instead of summer (WHY?). The seasonal reproductive trend is clearly shown in the histological analysis of oocyte development. The gametogenesis is typical of caridean shrimp. The oogenic processes in decapods comprises a proliferative phase where oogonia are produced by mitotic divisions in the germinal epithelium and a differentiative phase where a sexual response triggers the onset of gametogenesis and the development of oogonia into previtellogenic oocytes by meiotic divisions (Adiyodi and Subramoninan, 1983; Baeur, 2004). A pool of previtellogenic oocytes was present in the ovaries of $P$. multidentata at all times in all sites. In spring, the distribution of oocyte-sizes becomes slightly bimodal, indicating the start of vitellogenesis, which starts at oocytes sizes of around $180 \mu \mathrm{m}$ and is characterised microscopically by the presence of yolk granules in the cytoplasm. The developing oocytes are surrounded by a mono-layer of accessory cells involved in the transfer of nutrients into the growing cells. The proportion and size of vitellogenic oocytes in P. multidentata increases from spring to autumn, with the largest oocytes observed measuring between 1200-1400 $\mu \mathrm{m}$. The large size of mature vitellogenic oocytes (> $1400 \mu \mathrm{m})$ corresponds to the egg size (1870 $\mu \mathrm{m}$ in length) previously reported from ovigerous females (Company et al., 2001). This egg size is indicative of lecithotrophic larval development with a reduction in the number of larval stages (Baeur, 2004). Abbreviated larval development provides a higher larval survival probability and is typical of deep-sea caridean shrimp (Baeur, 2004). Deep-sea larvae are exposed to fluctuations in food supply and high predation risk during their plancktonic phase in the water column. Large, advanced larvae have the necessary reserves to develop to juvenile through a smaller number of instars, decreasing the time spent in the water column and therefore decreasing mortality risk (King and Butler, 1985; Clarke and Gore, 1992; 
Ramirez-Llodra, 2002; Baeur, 2004). We do not know the larval and recruitment stages of $P$. multidentata, and in general very little is known about larval ecology of deep-sea species (Young, 2003). Future studies focusing on these first stages of the life cycle of deep-sea species will provide essential information to understand the maintenance of a population and dispersal potential. This would be especially valuable when analysing commercial and associated species with the aim to develop management options.

\section{Acknowledgements}

The authors would like to thank the Captain and Crew of the fishing vessels Carme and Montserrat III, on board which the sampling was conducted Batis? This study is part of the Spanish project RECS II, supported by a CYCIT grant (REF, Batis?).

\section{References NEEDS UPDATING}

Baldwin, R. J., Glatts, R. C. and Smith, K. L. J. (1998). "Particulate matter fluxes into the benthic boundary layer at a long time-series station in the abyssal NE Pacific: composition and fluxes." DeepSea Research II 45: 643-665.

Baeur, R. T. (2004). Remarkable shrimps: adaptations and natural history of the Carideans. Oklahoma, University of Oklahoma, pp. 282.

Benthoux, J. P., Durieu de Madron, X., Nyffeler, F. and Tailliez, D. (2002). "Deep water in the western Mediterranean: peculiar 1999 and 2000 characteristics, shelf formation hypothesis, variability since 1970 and geochemical inferences." Journal of Marine Systems 33-34: 117-131.

Billett, D. S., Lampitt, R. S., Rice, A. L. and Mantoura, R. F. C. (1983). "Seasonal sedimentation of phytoplankton to the deep-sea benthos." Nature 302: 520-522.

Billett, D. S. M., Bett, B. J., Rice, A. L., Thurston, M. H., Galeron, J., Sibuet, M. and Wolff, G. A. (2001). "Long-terms change in the megabenthos of the Porcupine Abyssal Plain." Progress in Oceanography 50: 325-348.

Bozzano, A., Recasens, L. and Sartor, P. (1997). "Diet of European hake Merluccius merluccius (Pisces; Merluciidae) in the western Mediterranean (Gulf of Lions)." Scientia Marina 61: 1-8.

Canals, M., Puig, P., Durrieu de Madron, X., Heussner, S., Palanques, A. and Fabres, J. (2006). "Flushing submarine canyons." Nature 444: 354-357. 
Cartes, J. (1993). "Feeding habits of pasiphaeid shrimps close to the bottom on the western Mediterranean slope." Marine Biology 117: 45-468.

Cartes, J. E. and Sardà, F. (1993). "Zonation of deep-sea decapod fauna in the Catalan Sea (western Mediterranean)." Marine Ecology Progress Series 94: 27-34.

Cartes, J. E., Elizalde, M. and Sorbe, J. C. (2001). "Contrasting life-histories, secondary production, and trophic structure of Peracarid assemblages of the bathyal suprabenthos from the Bay of Biscay (NE Atlantic) and the Catalan Sea (NW Mediterranean)." Deep-Sea Research I 48: 2209-2232.

Company, J. B. and Sardà, F. (1997). "Reproductive patterns and population characteristics in five deep-water pandalid shrimps in the Western Mediterranean along a depth gradient (150-1100m)." Marine Ecology Progress Series 148: 49-58.

Company, J. B. and Sardà, F. (2000). "Growth parametres of deep-water decapod crustaceans in the northwestern Mediterranean Sea: a comparative approach." Marine Biology 136: 79-90.

Company, J. B., Cartes, J. E. and Sardà, F. (2001). "Biological patterns and near-bottom population characteristics of two pasiphaeid decapod crustacean species, Pasiphaea sivado and Pasipahea multidentata, in the Norhtwestern Mediterranean Sea." Marine Biology 139: 61-73.

Company, J. B., Maiorano, P., Tselepides, A., Politou, C.-Y., Plaity, W., Rotllant, G. and Sardà, F. (2004). "Deep-sea decapod crustaceans in the western and central Mediterranean Sea: preliminary aspects of species distribution, biomass and population structure." Scientia Marina 68 (Suppl. 3): 7386.

Company, J. B., Sardà, F., Puig, P., Cartes, J. and Planques, A. (2003). "Duration and timing of reproduction in decapod crustaceans of the NW Mediterranean continental margins: is there a general pattern?" Marine Ecology Progress Series 261: 201-216.

Eckelbarger, K. J. and Walting, L. (1995). "Role of phylogenetic constraints in determining reproductive patterns in deep-sea invertebrates." Invertebrate biology 114(3): 256-269.

Gage, J. (2003). Food inputs, utilisation, carbon flow and energetics. Ecosystems of the World. Ecosystems of the Deep Ocean. P. A. Tyler. Amsterdam, Elsevier. 28: 313-426.

Galéron, J., Sibuet, M., Vanreusel, A., Mackenzie, K. L., Gooday, A. J., Dinet, A. and Wolff, G. A. (2001). "Temporal patterns among meiofauna and macrofauna taxa related to changes in sediment geochemistry at an abyssal NE Atlantic site." Progress in Oceanography 50: 303-324.

Gooday, A. J. (1993). "Deep-sea benthic foraminiferal species which exploit phytodetritus: characteristic features and controls on distribution." Marine Micropaleontology 22: 187-205.

González-Gurriarán, E. and Olaso, I. (1987). "Spatial and temporal changes of decapod crustaceans from the continental shelf of Galicia (NW Spain)." Investigaciones Pesqueras 51: 323-341. 
Lampitt, R. S., Bett, B., Kiriakoulakis, K., Popova, E. E., Ragueneau, O., Vangriesheim, A. and Wolff, G. A. (2001). "Material supply to the abyssal seafloor in the Northeast Atlantic." Progress in Oceanography 50: 27-64.

Levin, L. A., Plaia, G. R. and Huggett, C. L. (1994). The influence of natural organic enchancement on life histories and community structure of bathyal polychaetes. Reproduction, larval biology, and recruitment of the deep-sea benthos. C. M. Young and K. J. Eckelbarger. New York, Columbia Universtity Press: 336.

Puig, P., Palanques, A., Guillen, J. and Garcia-Ladona, E. (2000). "Deep slope currents and suspended particle fluxes in and around the Foix submarine canyon (NW Mediterranean)." Deep-Sea Research I 47: 343-366.

Puig, P., Company, J. B., Sardà, F. and Palanques, A. (2001). "Responses of deep-water shrimp populations to the presence of intermediate nepheloid layers on continental margins." Deep-Sea Research I 48: 2195-2207.

Ramirez-Llodra, E. (2002). "Fecundity and Life-history Strategies in Marine Invertebrates." Advances in Marine Biology 43: 88-170.

Sardà, F., Calafat, A., Flexas, M. M., Tselepides, A., Canals, M., Espino, M. and Tursi, A. (2004). "An introduction to Mediterranean deep-sea biology." Scientia Marina 68 (Suppl. 3): 7-38.

Tyler, P. A., Campos-Creasy, L. S. and Giles, L. A. (1994). Environmental control of quasi-continuous and seasonal reproduction in deep-sea benthic invertebrates. Reproduction, Larval Biology and Recruitment of the Deep-Sea Benthos. C. M. YOung and K. J. Eckelbarger. New York, Columbia Universtity Press: 158-178. 


\section{Legends}

Figure 1. Map showing the bathymetry of the area around the Blanes canyon and the location of the sampling sites.

Figure 2. Population structure of Pasiphaea multidentata from the Blanes canyon area in Spring, summer, autumn and winter. Black squares, margin; Dark grey triangles, canyon wall; Grey circles, canyon head; $\mathrm{m} \mathrm{w}, \mathrm{c}=$ sample size at the margin, wall and canyon sites.

Figure 3. Sex ratio of Pasiphaea multidentata from 3 sites in 4 seasons. A, margin; B, canyon wall; C, canyon head. Plain bars, females; Dashed bars, males.

Figure 4. Percentage frequency of each ovary maturation stage of Pasiphaea multidentata in 3 sites and four seasons. A, margin; B, canyon wall; C, canyon head. SPR, spring; SUM, summer; AUT, autumn; WIN, winter. Light grey, resting stage (II); Dashed grey, initiation of maturation (III); Dark grey, maturing ovaries (IV); Black, mature ovaries (V).

Figure 5. Histological sections of ovaries from Pasiphaea multidentata. A, section showing a new cohort of previtellogenic oocytes developing amongst vitellogenic oocytes; $\mathrm{B}$, section of a developing ovary with previtellogenic and early vitellogenic oocytes; C, section showing early vitellogenic oocytes; D, section showing vitellogenic oocytes surrounded by accessory cells. ac, accessory cells; gvo, growing (early) vitellogenic oocytes; lg, lipidic granule; pvo, previtellogenic oocyte, vo, vitellogenic oocyte.

Figure 6. Oocyte size distribution of Pasiphaea multidentata from 3 sites (margin, wall and canyon) and 4 seasons. A, winter; B, spring; C, summer; D, autumn.

Figure 7. Mean size of vitellogenic oocytes of $P$. multidentata in the 3 sites and 4 seasons. Black square, margin; Dark grey triangle, canyon wall; Grey circle, canyon head. 
Table 1. Sampling sites, date and depth. M, margin $\left(41.6^{\circ} \mathrm{N} 2.8^{\circ} \mathrm{E}\right)$; W, wall $\left(41.5^{\circ} \mathrm{N}\right.$ $\left.3.0^{\circ} \mathrm{E}\right)$; $\mathrm{C}$, canyon $\left(41.6^{\circ} \mathrm{N} 2.8^{\circ} \mathrm{E}\right)$.

\begin{tabular}{|c|c|c|}
\hline Date & Site & Depth (m) \\
\hline \multicolumn{3}{|l|}{ Spring } \\
\hline \multirow[t]{3}{*}{$14 / 04 / 2003$} & $\mathrm{M}$ & 600 \\
\hline & $\mathrm{W}$ & 585 \\
\hline & $\mathrm{C}$ & 585 \\
\hline \multirow{3}{*}{$29 / 05 / 2004$} & $\mathrm{M}$ & 667 \\
\hline & $\mathrm{W}$ & 603 \\
\hline & $\mathrm{C}$ & NS \\
\hline \multicolumn{3}{|l|}{ Summer } \\
\hline \multirow[t]{3}{*}{$20 / 08 / 2003$} & $\mathrm{M}$ & 700 \\
\hline & $\mathrm{W}$ & 520 \\
\hline & $\mathrm{C}$ & 364 \\
\hline \multicolumn{3}{|l|}{ Autumn } \\
\hline \multirow[t]{3}{*}{$30 / 09 / 2003$} & $\mathrm{M}$ & 631 \\
\hline & W & 567 \\
\hline & $\mathrm{C}$ & 502 \\
\hline \multirow[t]{3}{*}{$17 / 12 / 2003$} & $\mathrm{M}$ & $512-530$ \\
\hline & $\mathrm{W}$ & $402-512$ \\
\hline & $\mathrm{C}$ & $475-512$ \\
\hline \multicolumn{3}{|l|}{ Winter } \\
\hline \multirow[t]{3}{*}{$03 / 02 / 2004$} & $\mathrm{M}$ & 512 \\
\hline & $\mathrm{W}$ & $384-510$ \\
\hline & $\mathrm{C}$ & 512 \\
\hline \multirow{3}{*}{$10 / 03 / 2004$} & $\mathrm{M}$ & 640 \\
\hline & $\mathrm{W}$ & 567 \\
\hline & $\mathrm{C}$ & 585 \\
\hline \multicolumn{3}{|l|}{ Spring } \\
\hline \multirow[t]{3}{*}{$21 / 04 / 2004$} & $\mathrm{M}$ & 695 \\
\hline & $\mathrm{W}$ & 585 \\
\hline & $\mathrm{C}$ & $\mathrm{NS}$ \\
\hline
\end{tabular}




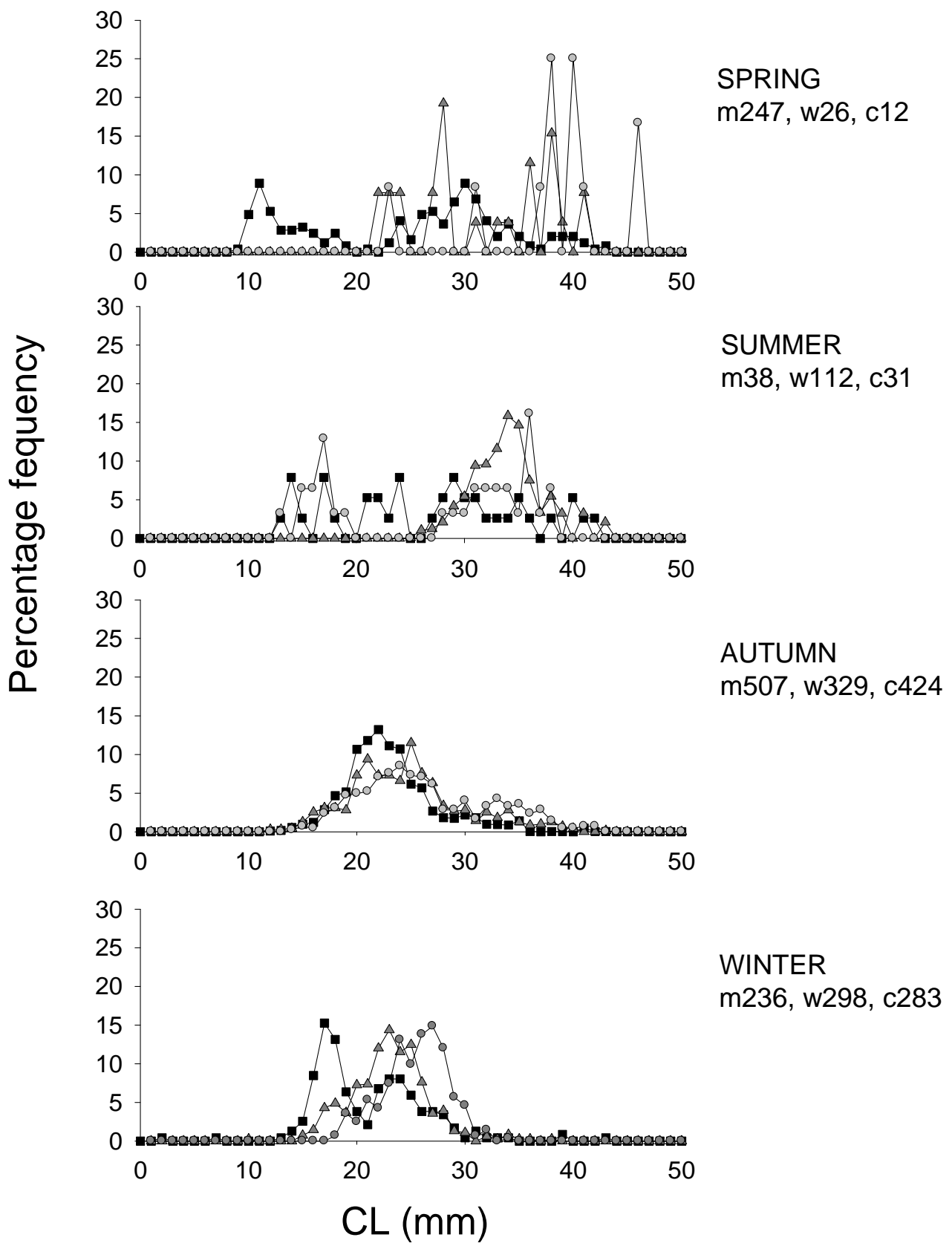

Figure 2. Ramirez-Llodra et al. 


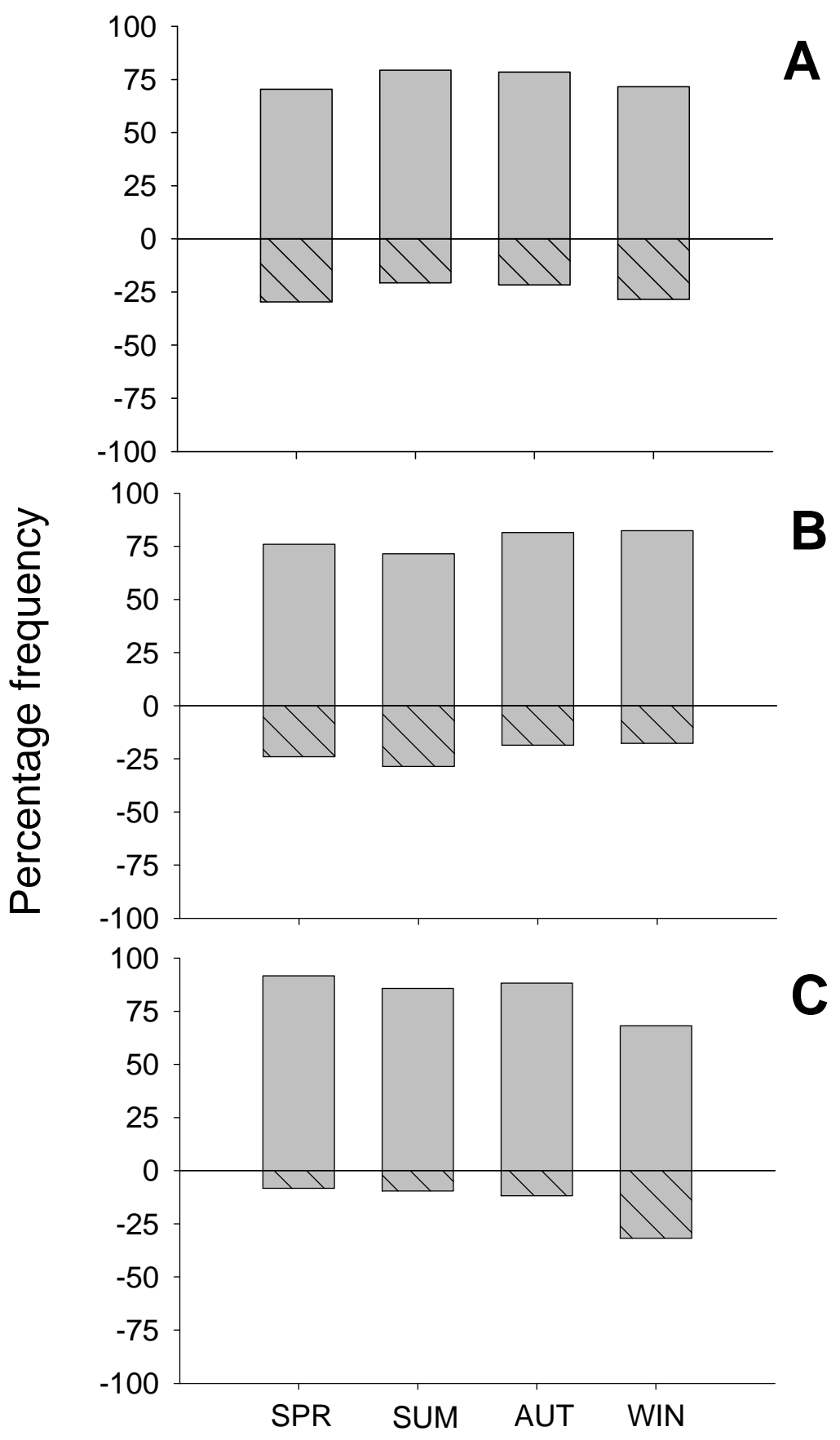

Figure 3. Ramirez-Llodra et al. 


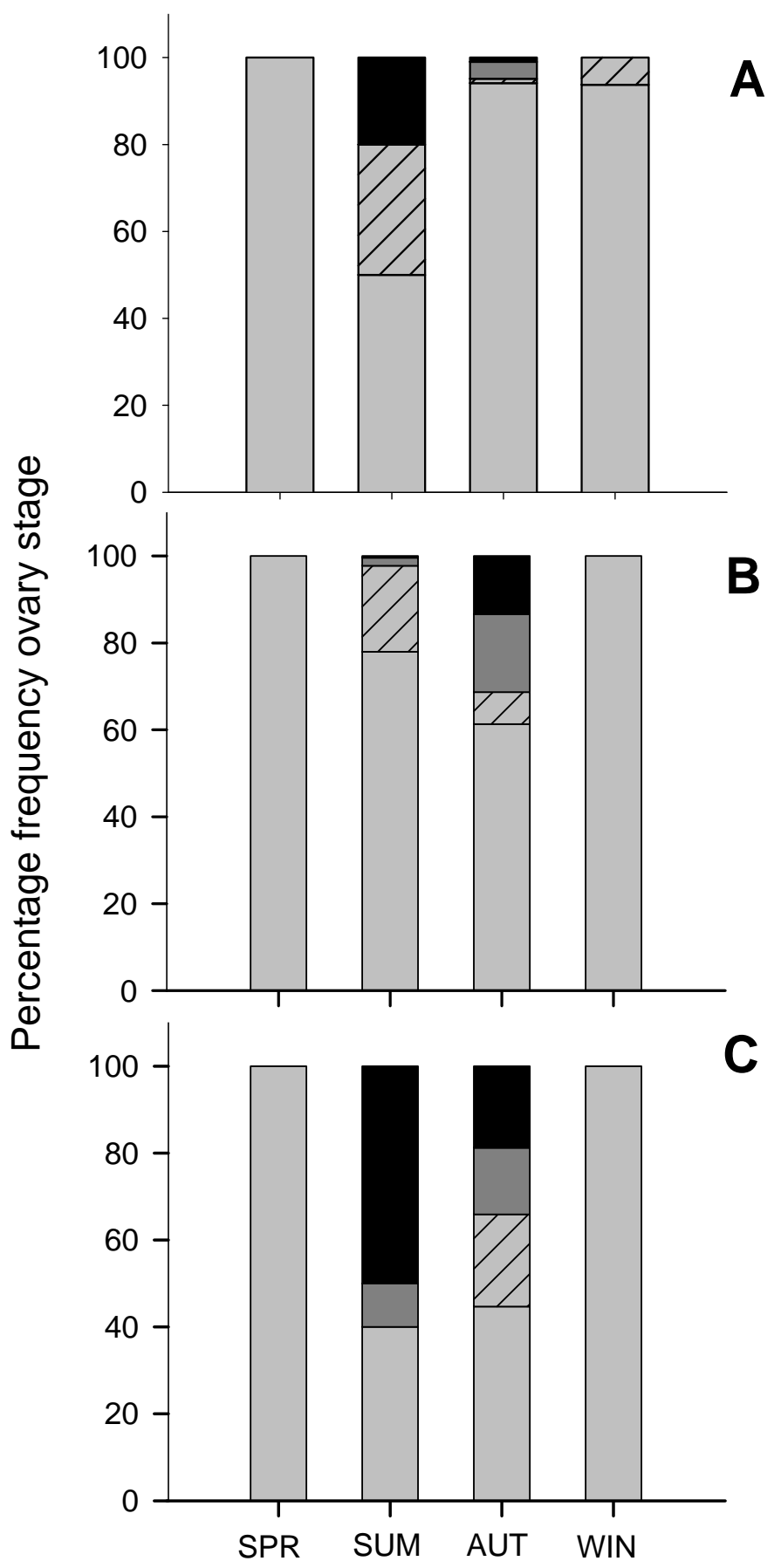

Figure 4. Ramirez-Llodra et al. 


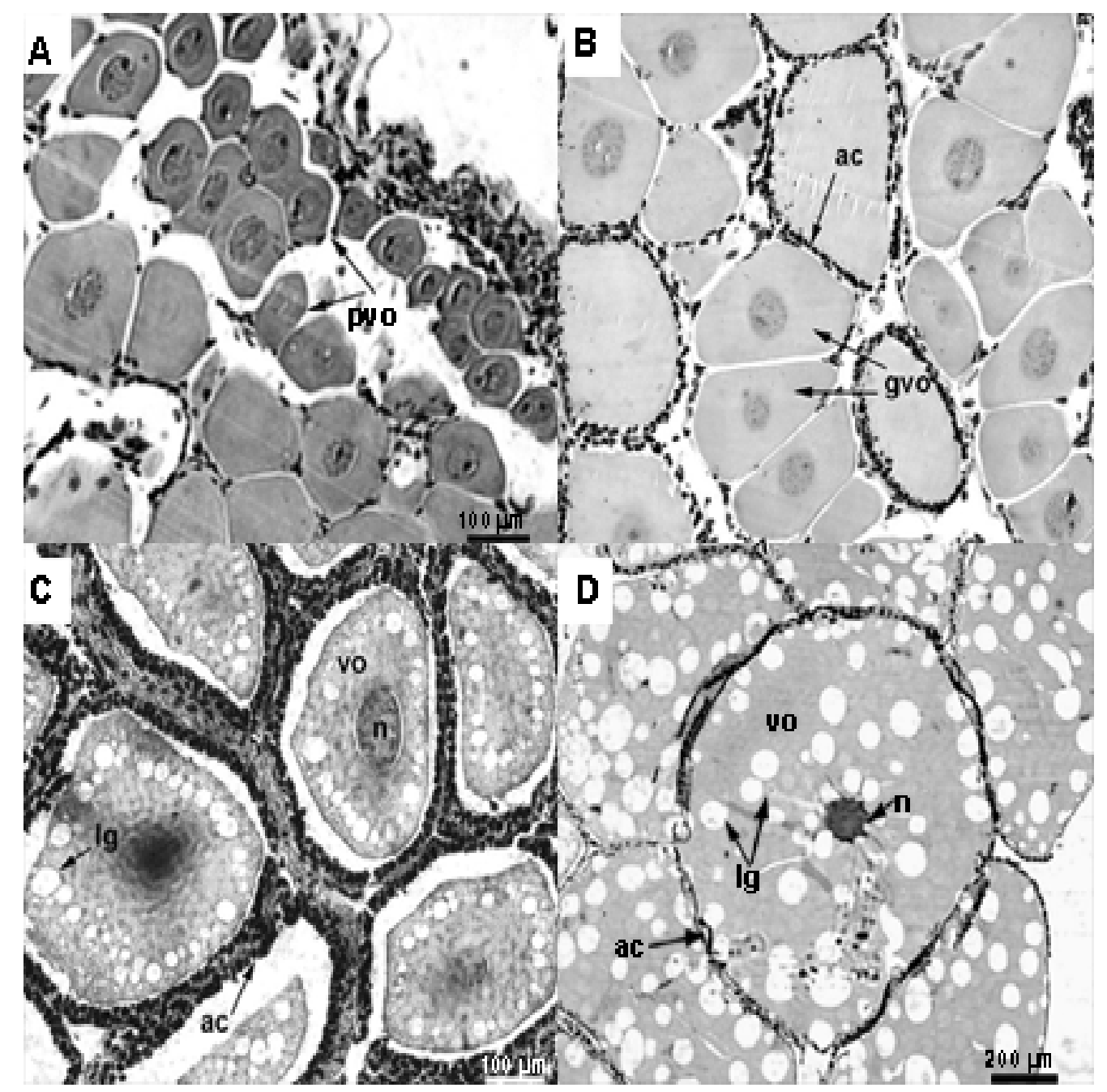

Figure 5. Ramirez-Llodra et al. 


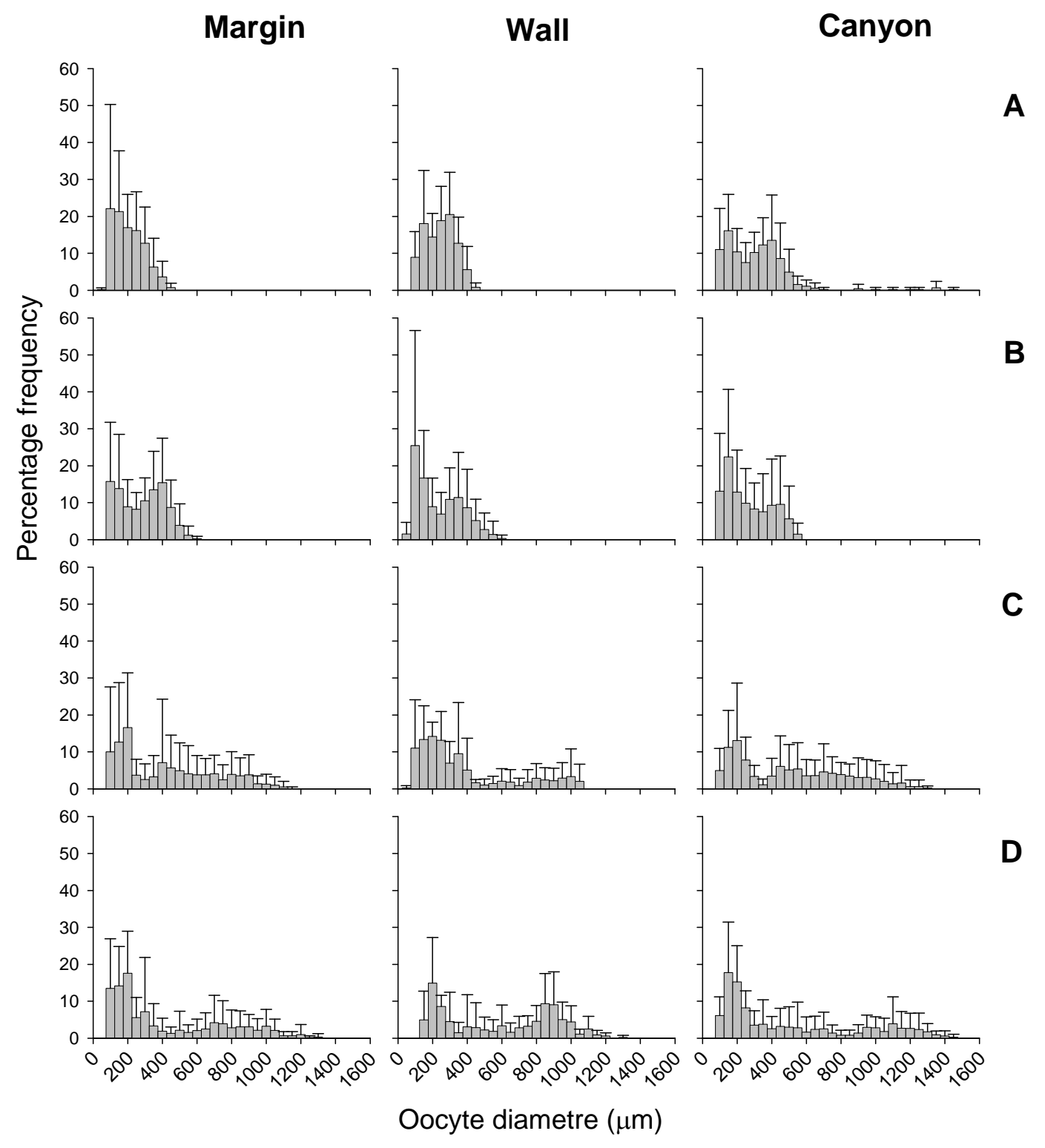

Figure 6. Ramirez-Llodra et al. 


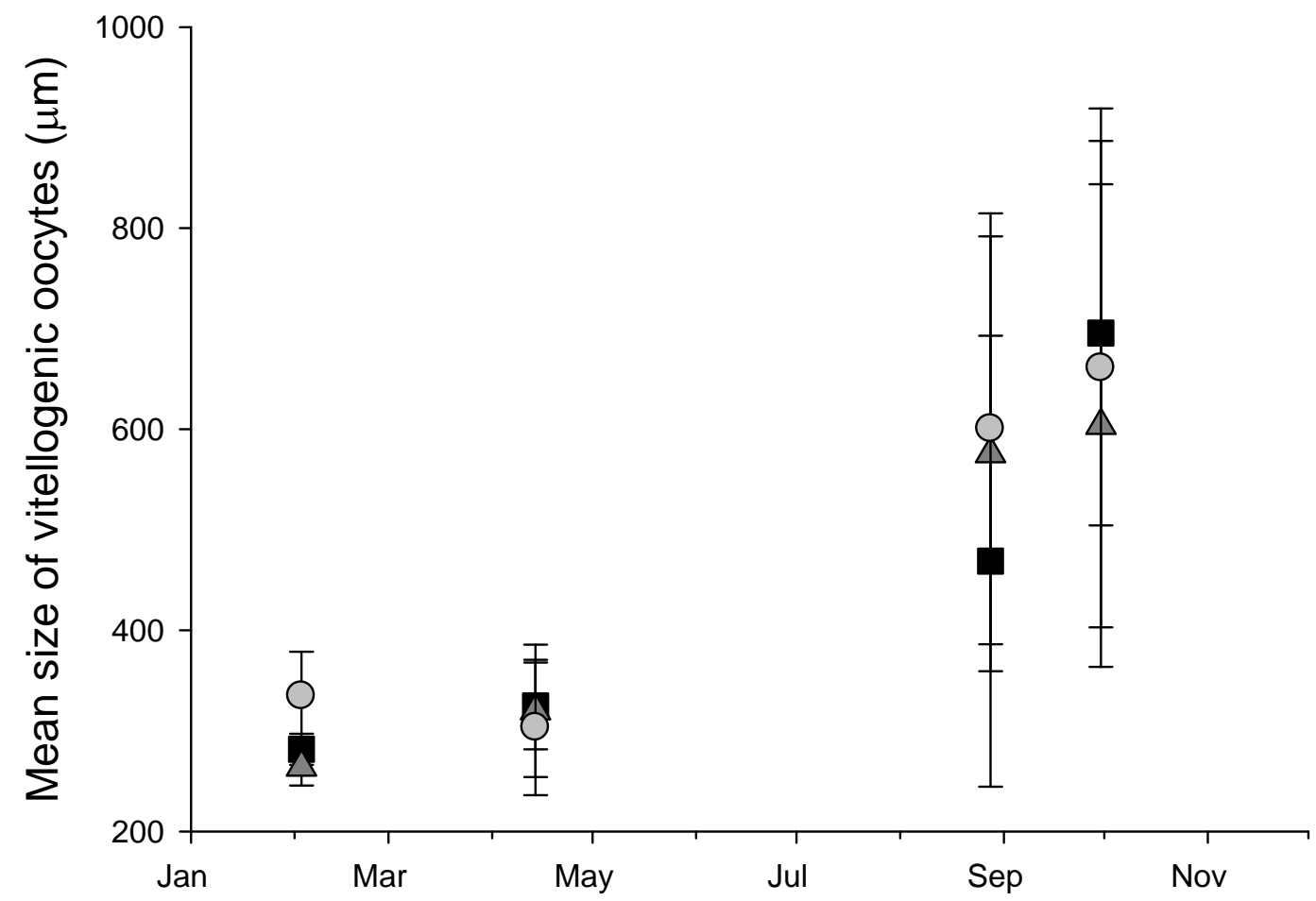

Figure 7. Ramirez-Llodra et al. 